University of Nebraska - Lincoln

DigitalCommons@University of Nebraska - Lincoln

Robert G. Fuller Publications and Presentations Research Papers in Physics and Astronomy

October 2007

\title{
Can One Book Really Transform Your Career?
}

Robert Fuller

rfuller@neb.rr.com

Follow this and additional works at: https://digitalcommons.unl.edu/physicsfuller

Part of the Physics Commons

Fuller, Robert, "Can One Book Really Transform Your Career?" (2007). Robert G. Fuller Publications and Presentations. 30.

https://digitalcommons.unl.edu/physicsfuller/30

This Article is brought to you for free and open access by the Research Papers in Physics and Astronomy at DigitalCommons@University of Nebraska - Lincoln. It has been accepted for inclusion in Robert G. Fuller Publications and Presentations by an authorized administrator of DigitalCommons@University of Nebraska - Lincoln. 


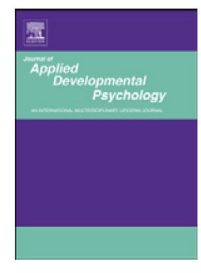

Published in

\section{Journal of Applied Developmental Psychology}

Volume 29, number 5 (September-October 2008), pp. 412-414;

doi 10.1016/j.appdev.2008.06.006. Copyright (C) 2008 Elsevier Inc. Used by permission.

http://0-www.sciencedirect.com.library.unl.edu:80/science/journal/01933973

\section{Book review}

\section{Can one book really transform your career?}

Bärbel Inhelder and Jean Piaget, The growth of logical thinking from childhood to adolescence: An essay on the construction of formal operational structures. Basic Books, New York, 1958, ISBN: 041521002X (cloth), xxvi+356 pp., \$25

Can one book really transform your career? The answer is yes. How do I know? Because the basic ideas of this book, which became available in English 50 years ago, did it to me.

In the early 1970s I was a young research physicist and a faculty member at the University of Nebraska-Lincoln (UNL) struggling to teach college general physics to students, most of whom were seeking a career in a medical profession. In spite of my best efforts in the traditional lecture/recitation style of instruction the students were not able to perform up to my expectations. I was puzzled by this experience. (Later I came to know this as an experience of disequilibration, according to Piaget.)

In January 1973 I was sitting at the back of a large hotel convention room listening to a presentation by Professor John Renner (1972), University of Oklahoma. He was telling how the world of physics looked to students who were using concrete operational reasoning according to the work of Jean Piaget. The mental light of recognition went on in my mind. Obviously, if I was going to be able to make sense out of the poor performance of my students I was going to have to find out more about this Piaget person. During his talk, Dr. Renner had mentioned the book on formal operations by Inhelder and Piaget. (To my present embarrassment, I remember telephoning an educational psychologist who was the head of the Teaching and Learning Center at UNL in 1973 and asking if he had ever heard of Piaget!)

What are the basic ideas in this volume that transformed my career?

First, each of the first 14 chapters introduces a task involving a simple experimental system in physics or chemistry. Students are asked to predict and explain the behavior of the system as they engage in the task and observe the results of their actions. For example:

A given number of disparate objects are presented to the subject who is asked to classify them according to whether or not they float on water. Then (the classification completed) he is asked to explain the basis of his classification in each case. Next, the subject himself experiments, having been given one or several buckets of water; finally, he is asked to summarize his observations, this latter request suggesting that he is to look for a law, if this has not already spontaneously occurred to him. (p. 20)

Basic idea: Simple physical tasks or puzzles can be used to explore students' reasoning patterns. As an experimental research physicist, I loved this idea! Physicist Robert Karplus was inspired by this to publish a series of articles on reasoning beyond elementary school (Fuller, 2002).

Second, each of these 14 chapters contains partial transcripts of students' oral explanations of the behavior of the various physical systems they observe. Inhelder and Piaget analyze the reasoning behind these explanations, showing that even "wrong" answers provide important insight into the reasoning patterns of the students. For example:

ALA $(11 ; 9)$ [age 11 years, 9 months]: "Why do you say that this key will sink?" - "Because it is heavier than the water." - "The little key is heavier than that water?" [the bucket is pointed out]. - "I mean the same capacity of water would be less heavy than the key." - "What do you mean?" - "You would put them [metal or water] in containers which contain the same amount and weigh them." ...

We see how, rejecting any suggestion that they relate the weight of the objects in question to the weight of all the water in the receptacle, ... subjects [such as ALA] reach the point of comparing the first weight to that of an equivalent volume of water... ALA [is] able to reason about the amount of water equal to the volume of the object... [T] [ [concrete operational] schema [to which younger subjects assimilate the present task] is transformed into a relationship ... between the weight and volume of the object in question and the corresponding weight and volume of water displaced by that object (pp. 38-39). 


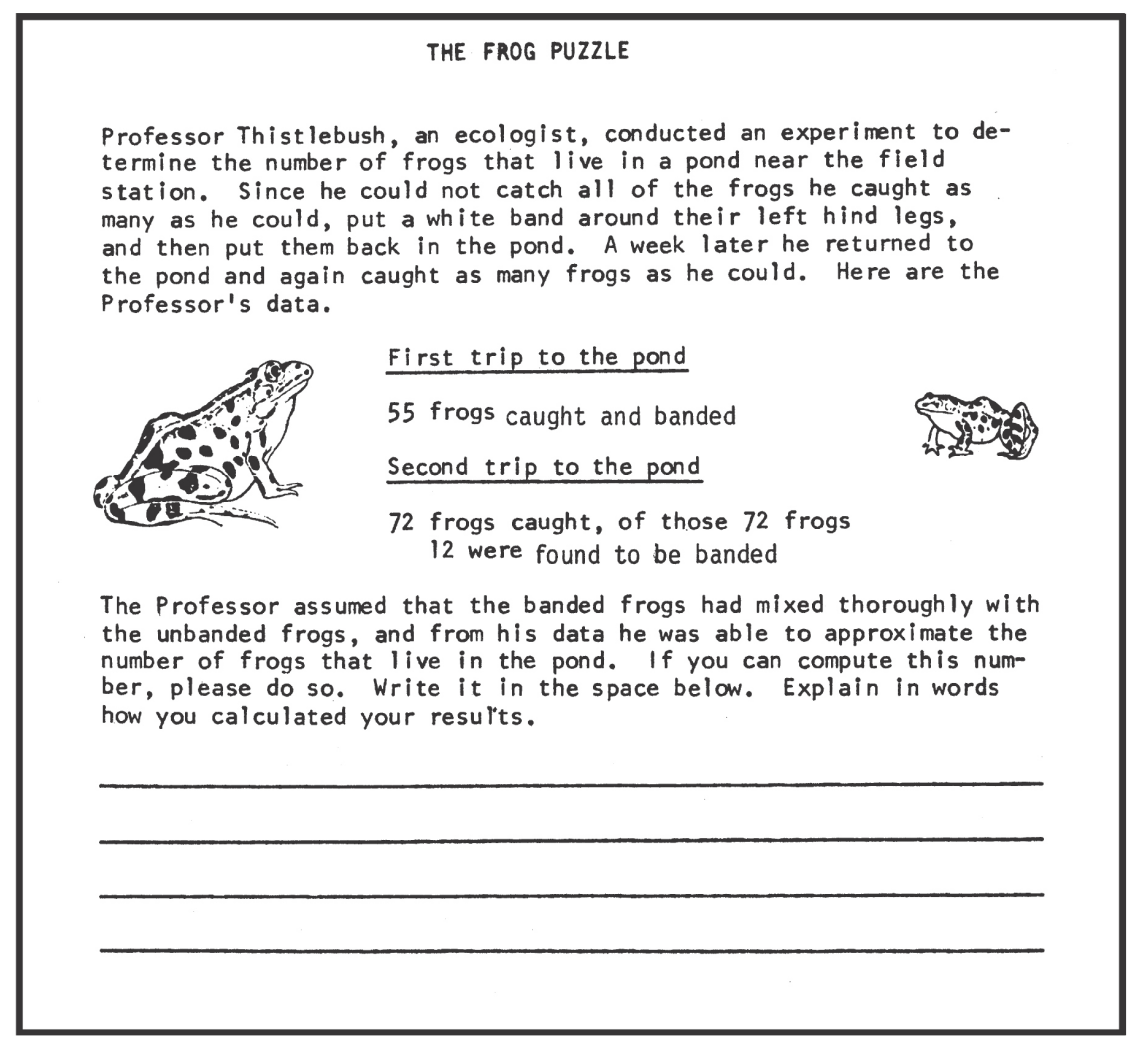

Figure 1: The Frog Puzzle

Basic idea: Answers to problems are not just right or wrong, they are windows into the reasoning patterns of the students. Wow! To an experimental research physicist who never had to consider asking an electron why it did something, this was a big eye opener and made me love simple physics puzzles even more. This idea has spawned important research on students' misconceptions (Arons, 1997; McDermott, 2001).

The Inhelder-Piaget style of semi-clinical interviews has been embraced as a research tool by physicists. The work of Arons and Karplus (1976) led to the development of physics education research (PER). Now more than a dozen university physics departments have PER groups and doctoral students in physics may elect to do their dissertation in PER. There is an annual PER conference (called PERCs, see http://web.phys.ksu.edu/perc2007/ ) and the results of PER can be published in physics journals as well as the on-line PER journal ( http://prst-per.aps.org/ ). The University of Maryland PER group has a website that links to most PER groups ( http://www.physics.umd.edu/perg/ ) and there is a PER listserver ( $\underline{\text { PHYSLRNR@LISTSERV. }}$ BOISESTATE.EDU ). A survey of the results of PER work was published by McDermott and Redish (1999).

Third, students grow into logical thinking and scientific reasoning. The theme of each of the first few chapters of the book is how concrete reasoning serves as the basis for the development of formal thinking. Somehow the "wrong" explanations of the students serve as a basis for their growth into more mature patterns of reasoning. Inhelder and Piaget stress that developing individuals actively construct advanced reasoning schemes rather than simply internalizing them.

Basic idea: Students grow into their ability to do scientific reasoning. They may not have had growth encouraging experiences in science courses before getting to college, hence a college physics course needs to take on the additional role of provoking the students to develop more mature reasoning patterns, not just mastering physics content.

Fourth, the development of logical thinking depends upon the maturation of the nervous system, experience acquired in interaction with the physical environment, and the influence of the social milieu.

Basic idea: Students can be put into a social situation that requires them to interact with the physical environment in ways that can enhance intellectual growth. Robert Karplus (1974) had sought to embed Piaget's ideas into an instructional strategy he called a Learning Cycle. We translated Karplus' strategy into a multidisciplinary Piagetian-based program entitled ADAPT (Accent on Developing Abstract Processes of Thought) for first-year students at UNL.

The ADAPT program existed from 1975 until 1997. For most of those years I taught an introductory physics course in the program and served as its director. My professional career was transformed from experimental solid-state physics to a quest for Piagetian-based physics education and the development of formal reasoning by college students.

An evaluation of the influence of the ADAPT program on students was published in 1980 (Moshman, Johnson, Williams, Tomlinson-Keasey, \& Eisert, 1980). The ADAPT faculty espoused a constructivist, Piagetian approach and led college faculty development workshops at more than a hundred locations in the 1970s and 1980s. A summary of Piagetian programs was pub- 
lished in the Chronicle of Higher Education upon the death of Piaget in 1980 (Jacobson, 1980). I published a brief history of the ADAPT program in The Genetic Epistemologist (Fuller, 1998, 1999) and the ADAPT materials are now available on the UNL Digital Commons website (http:// digitalcommons.unl.edu/adapt/).

Fifth, the key ingredient in intellectual growth is the mental self-regulation in which students engage. Since, according to Piaget, the human mind naturally seeks equilibrium, an experience that produces disequilibrium can foster intellectual growth through equilibration.

Basic idea: Puzzlement is a key element of developing scientific reasoning. Every graduate student in physics has been confronted by problems that seemed to defy solution. Success on such problems often involves an "Ah-ha" experience in which a solution becomes obvious. So every physicist has had a personal professional experience of disequilibration pushing one toward a new, and more advanced, equilibrium. Hence, the Piagetian model for intellectual growth resonates with the professional experiences of physicists. It makes good sense to us, as physics professors, to try to construct learning/growth experiences in physics classes that provide students with the right amount of puzzlement to encourage them to reason their way to mental equilibrium. Of course we must be sure to use a grading rubric that recognizes scientific reasoning, not just the regurgitation of physics content.

Sixth, and finally, Chapter 17 presents eight formal structured operational schemata: (1) the combinatorial operations; (2) proportions; (3) coordination of two systems of reference; (4) the concept of mechanical equilibrium; (5) the notion of probability; (6) the notion of correlation; (7) multiplicative compensation; and (8) forms of conservation that go beyond direct empirical verification. These operational schemata, suggest the authors, share the underlying logical structure of an INRC group, whatever that is.

Basic idea: Formal operational thought has an internal structure that can be treated as reasoning patterns used by students. So we could develop simple written puzzles that would give us a glimpse into the use of formal reasoning by our students. The most complete of these assessments is the test for scientific reasoning by A. E. Lawson (1978). We frequently gave the Frog Puzzle (Figure 1), a simple test of proportional reasoning, to our ADAPT students in an English class. In general, we found about half used proportional reasoning on this task (Thornton \& Fuller, 1981).

Unfortunately, almost every chapter in The growth of logical thinking employs a set of 16 binary logical operations in a highly technical effort to explain the use of mental operations by the subjects. I did not find this use of propositional logic to be of much help to me as an educator, nor does it appear that Piaget's logical analysis of reasoning has withstood the challenge of 50 years of research and critique since the publication of this book.

Furthermore, the somewhat ponderous prose of major portions of this book does not make it a coffee table read. There are other books by Piaget that can bring more excitement about his ideas to an educator. Major sections of Piaget's (1974) little paperback book, To understand is to invent, were extremely helpful to me. Eleanor Duckworth and David Elkind have been my favorite American interpreters of the work of Piaget for educators. My recommendation is to get your hands on Inhelder and Piaget's seminal book (it is probably in a library near you), read at least the first part of each of the first 14 chapters, and try as much of the rest as you can stand. Then set this book aside and read Piaget's (1974) To understand is to invent, Duckworth's (1996) The having of wonderful ideas, and Elkind's (1974) Children and adolescents: Interpretive essays on Jean Piaget.

The celebration of our students having their own wonderful ideas is the fundamental reward of being an educator. With that in mind, if you get caught up in the content autocracy of teaching your discipline within a formal educational institution, I hope that the voice of Jean Piaget will haunt you in your sleep, saying, "Have you forgotten about the development of reasoning?"

\section{References}

Arons, A. B. and Karplus, R. (1976). Implications of accumulating data on levels of intellectual development. American Journal of Physics, $44,396$. Arons, A. B. (1997). Teaching Introductory Physics. New York: Wiley.

Duckworth, E. (1996). "The having of wonderful ideas" \& other essays on teaching and learning (2 ${ }^{\text {nd }}$ edition). New York: Teachers College Press.

Elkind, D. (1974). Children and adolescents: Interpretive essays on Jean Piaget. New York: Oxford University Press.

Fuller, R. G. (1998). ADAPT: A multidisciplinary Piagetian-based program for college freshmen (Part 1). The Genetic Epistemologist, $26(2), 1-3$.

Fuller, R. G. (1999). ADAPT: A multidisciplinary Piagetian-based program for college freshmen (Part 2). The Genetic Epistemologist, 27(3), 1-3.

Fuller, R. G. (2002). A love of discovery: Science education - The second career of Robert Karplus. New York: Kluwer Academic/Plenum.

Jacobson, R. L. (1980). Theories of Piaget, who died this month, inspire growing band of U.S. professors. The Chronicle of Higher Education, September 29. Karplus, R. (1974). SCIS teacher's handbook. Berkeley, CA: Lawrence Hall of Science.

Lawson, A. E. (1978). The development and validation of a classroom test of formal reasoning. Journal of Research in Science Teaching, 15, 11-24. The test is available from the following website:

http://cresmet.asu.edu/proj_res/msp/course3/sp06/investigations/2-How\%20Students\%20Think/Lawson_Scientific_Reasoning_Test.pdf

McDermott, L. C. (2001). Physics education research - The key to student learning, American Journal of Physics, 69, 1127-1137.

McDermott, L. C., and Redish, E. (1999). Resource letter PER-1: Physics education research. American Journal of Physics, 67, 755-767.

Moshman, D., Johnson, S., Williams, V., Tomlinson-Keasey, C. and Eisert, D. (1980). ADAPT: The first five years. In R. G. Fuller (Ed.) ADAPT: A Piagetian based program for college freshmen (pp. 115-121). Lincoln, NE: University of Nebraska.

Piaget, J. (1974). To understand is to invent. New York: Penguin.

Renner, J. W. (1972). Intellectual development and science teaching. AAPT Announcer, 2(4), 29.

Thornton, M.C., \& Fuller, R.G. (1981). How do college students solve proportion problems? Journal of Research in Science Teaching, 18, 335-340.

Robert G. Fuller

Professor Emeritus of Physics,

University of Nebraska, Lincoln, NE 68588-0111

E-mail address: rfuller@neb.rr.com 